\title{
The challenge of applying governance and sustainable development to wildland fire management in Southern Europe
}

\author{
Susana Aguilar • Cristina Montiel
}

Received: 2010-09-04; Accepted: 2010-12-20

(c) Northeast Forestry University and Springer-Verlag Berlin Heidelberg 2011

\begin{abstract}
This paper discusses participatory processes in wildland fire management (WFM). Participation is an essential element of both the European Sustainable Development (SD) Strategy and the White Paper on Governance. Governance and SD have thus become an interconnected challenge to be applied to WFM (as a sub-area in forest policy), amongst other policies. An overspread weakness in WFM is lack of real participation of stakeholders. Absence of (or deficient) participation can seriously impair contribution of this group to WFM in high-risk areas and runs counter governance and the SDS. Further, this weakness might prevent an efficient use of fire as a land management tool (prescribed burning, $\mathrm{PB}$ ) and as a technique for fighting wildfire (suppression fire, SF). Even though these fire practices have been well known in many different places, they have been increasingly neglected or prohibited over time in Southern Europe. At present, forest and fire fighting administrations are turning their eyes back on them and analyzing the benefits of using fire in relation to preventive and suppressive actions. Therefore, participatory and diffusion mechanisms (the latter adopting the shape of national and international experts' networks) are required in order to solve the socalled fire paradox: that is, the need to move from a one-dimensional perception of the negative impacts of fire to a more sophisticated one that also stresses its positive effects. Governance, based on broad social participation, and diffusion, through fire networks, are of utmost importance in order, first, to diminish long-standing suspicion amongst different interests as to the use of fire and, secondly, to diffuse best practices associated with PB and SF. Most importantly, the EU should exercise its
\end{abstract}

Foundation project: This paper has to be framed within the FIRE PARADOX Integrated Project, "An innovative approach of Integrated Wildland Fire Management Regulating the Wildfire Problem by the Wise use of Fire: solving the Fire Paradox", financed by the VI Framework Programme, Sub-priority 6.3 Global Change and Ecosystems (www.fireparadox.org).

The online version is available at http://www.springerlink.com

Susana Aguilar $(-$ ) C Cristina Montiel

Complutense University of Madrid, Somosaguas Campus Pozuelo de Alarcón 28223, Spain

E-mails: saguilar@cps.ucm.es; crismont@ghis.ucm.es

Responsible editor: Chai Ruihai environmental leadership so that these new fire practices and sustainable WFM are diffused across the international arena.

Keywords: governance; sustainable development; forestry policy; wildfire management; social participation

\section{Introduction}

Governance is a catchword that has come to symbolize good government under new, more complicated, and uncertain circumstances. Starting out with the internationalization and Europeanization of national policies, the decentralization processes that have affected a number of countries -creating multi-level polities-, and following with the new forms of partnership between public and private actors, governance is a new type of government that aspires to tackle new and old problems with mechanisms based on transparency, participation, and accountability (Mette 2004). Further, governance is closely linked to the European Union (EU) sustainable development strategy (SDS), in the sense that sustainability has to be accomplished through governance mechanisms. Governance and SD have thus become an interconnected challenge to be applied to public policies, forest policy being one of them.

Forest policy embraces a set of strategies, measures and actions whose aim is forestland planning and forest management (Glück and Voitleithner, 2004). Although frequently neglected, a major issue in EU forest policy (Even though there is no EU forest policy as such, but rather a package of forestry-related measures and initiatives, we will use this term for the sake of simplicity) is wildland fire management (WFM). This issue is most pressing in certain European countries: as wildfire is a worrying hazard in the Mediterranean region, preventive and suppressive actions have been usually included in different programmes (e.g. national and regional forest plans, N/RFP). The most frequently considered measures so far have been: fuel management; construction and conditioning of defensive infrastructures; public awareness and information campaigns; and the application of detection and extinction systems. A common weakness in the political process, as well as in legislation and planning documents, related to 
WFM is the lack of real participation of stakeholders. Absence of (or deficient) participation can seriously impair contribution of this group to WFM in high-risk areas and runs counter governance and the SDS. Alongside the need for empowerment of local groups, measures should be taken with a view to improving, first, accountability when adopting preventive and suppressive actions, and, secondly, multi-sectoral coordination and multilevel implementation (especially in decentralized countries) in WFM.

Further, conflict resolution methodologies concerning fire use in the Mediterranean countries are badly needed. The use of fire as a land management tool (prescribed burning) and as a technique for fighting wildfire (suppression fire) is well known in many European places but has been increasingly neglected over time. Recently, forest and fire fighting administrations are turning their eyes back on this practice and analyzing in greater detail the benefits of using fire in relation to preventive and suppressive actions. Therefore, participatory mechanisms, lesson-drawing, know-how transfer and training schemes are required in order to solve the so-called fire paradox; that is, the need to move from a one-dimensional perception of the negative impacts of fire to a more sophisticated one that stresses its positive effects. Learning processes on fire use should also be diffused through the existing national and international fire management networks. This last point is crucial as the use of suppression fire demands highly qualified personnel who possess technical skills, an insight into traditional socio-spatial structures and a well-established communication with the local communities.

Following a deductive logic (from broad-theoretical issues down to specific-empirical ones), the objectives of this paper will be: (1) to give a brief overview of the connection between governance and SD in the EU as well as to debate, more specifically, participatory issues and diffusion processes which are of utmost importance if WFM is to be applied effectively; (2) to analyze governance and SD in the context of EU forest policy in order to focus, later on, upon WFM itself ; to discuss both, the need to bring back certain fire practices (prescribed burning and suppression fire), and the conflict between different interests (locals vs fire services) that this "revival" is provoking; (3) to introduce Southern Europe by making a succinct reference to the so-called "Mediterranean syndrome"; to describe forestry and fire-related institutional frameworks and political outputs in the region; and to review the existing fire networks, and different learning and diffusion processes, which can help fire practices be implemented again.

In the concluding section, we argue that a sustainable forest policy (more precisely, a sustainable WFM) has to be flanked by governance mechanisms based on broad social participation and diffusion processes. The role of stakeholders (basically, local communities, forest owners, fire technicians and local and regional administrations) and fire networks is crucial in order, first, to diminish long-standing suspicion amongst different interests as to the use of fire and, secondly, to diffuse practices associated with prescribed burning and suppression fire that have proved beneficial in certain localities. We finally advocate that the EU should exercise its environmental leadership so that these new fire practices are diffused across the international arena.

It should be mentioned that this article is primarily based on a thorough analysis of primary sources (N/RFP and other official documents in different EU countries, with a special focus on Spain, France, Portugal and Italy). More importantly, a questionnaire elaborated by the Spanish working team (based on the Complutense University), which has participated in the EUfunded research project, has been applied to the forest-related bureaucratic and political staff in the EU so as to make up for information gaps and unclear, incomplete or contradictory information contained in primary sources ${ }^{1}$.

\section{Governance and sustainable development in the EU}

Although the term governance can etymologically "be traced back to the Greek verb kubernân (to pilot or steer) and was used by Plato with regard to how to design a system of rule" (Mette 2004), the concept that we will be using here re-emerged in the 1980 s with a meaning broader than that of government. Unlike government, which refers to (vertical) rule with authority, governance entails a different type of rule (horizontal). Oddly enough, governance has been "prodded from above by international and regional organizations, and pressured from below by a broad variety of non-governmental organizations" (Lafferty 2004). Governance can be defined as the totality of mechanisms and instruments available for influencing social change in preordained directions. As spelt out by the White Paper on European Governance, the principles of good governance are openness, participation, accountability, efficacy and coherence ${ }^{2}$.

Coincidental or overlapping demands for governance from both top-down and bottom-up actors have ended up in an allencompassing and undisputed agreement about the intrinsic virtues of the concept. Something similar seems to have hap-

\footnotetext{
${ }^{1}$ Through the Joint Research Centre (JRC) in the European Commission, the questionnaire was sent to the experts of the Working Group of Forest Fire Prevention (WGFFP). The mailing list was drawn out of the attendants to the experts' meeting held in Brussels on March the 24th 2006. 17 countries (Austria, Bulgary, Cyprus, Germany, Greece, Eslovenia, Spain, Finland, France, Croacia, Hungary, Italia, Lithuania, Letonia, Poland, Portugal and Sweden) participated in the meeting http://ec.europa.eu/environment/forests/wgffp.htm. The answers to the questionnaire were received in between December 2006 and December 2007. The number of answers amounted to 11 (Cyprus, Eslovenia, Spain, France, Greece, Italy, Lihtuania, Letonia, Poland, Portugal and Sweden) plus 17 from all the autonomous regions in Spain. More information on www.fireparadox.com

${ }^{2}$ In 2001, the European Commission published the White Paper on European Governance, in which a reform of the EU decision-making processes and of its institutions was put forward. In order to achieve this aim a number of proposals were adopted, such as Regulation 1049/2001/EC, that facilitates public access to EU documents; Directive 2003/4/EC, related to public access to environmental information; and Directive 2003/35/EC, that contributes to public participation in the elaboration of certain plans and programmes while smoothing access to justice.
} 
pened with the notion of SD, that has also enjoyed unrivalled popularity after the publication in 1987 of the Brundtland Report, Our Common Future, and the celebration of the UN-sponsored Summit in Rio in 1992. It goes without saying that SD constitutes the most ambitious challenge in the history of mankind: how to maintain (in developed countries) and achieve (in developing countries) development in a way that sustains itself over time, thereby integrating the three dimensions of development (economic, social and environmental) in a global and long-term strategy. This challenge embraces not only substance (efficient outcomes) but also procedures: sustainability is to be attained through social participation and empowerment, decisions should be open and transparent and decision-makers should be held accountable. It is the procedural side of SD which is clearly linked to governance.

Participatory processes and governance mechanisms in wildland fire management

N/RFP in all countries refers to the need for stakeholders and other groups to participate in the forestry field and acknowledge the implementation of some type of participation. Although there is consensus on what might be called the normative argument related to sustainability, which contends that "the enhancement of public participation is... an essential characteristic of governance for SD", differences can be easily detected in relation to three issues: (1) who is called upon to participate; (2) "the mechanisms through which such participation can be organised"; (3) "the contribution that different participatory traditions can make to the realisation of SD" (Meadowcroft 2004).

More specifically, very few references can be found in forestry-related official texts about these three most important questions which surround participatory processes. That is, sustainable forest management must necessarily be participated (the democratic mandate is inescapable), but who should participate, how, and what results of this participation can be expected are not at all clear (the combination of the "who" with the "how" is presented in Table 1).

The "who" question refers to the demos of a particular policy and has been frequently addressed by identifying two types of audience: a narrow one (the stakeholders or target-groups, following the principle of shared responsibility), and a broad one (the public in general). If we connect the "how" question (i.e. the choice between different mechanisms of participation) with the first type of audience, a number of participatory techniques can be put into practice. However, when applied to the second type of audience (the public), the "how" question has to confine itself to information or educational campaigns that aim to increasing social awareness about certain pressing topics (Table 1: A cell). The need for democratic governments to be seen as acting legitimately has sometimes led them to adopt consultation mechanisms in the shape of official web pages that allow the public to express their views on certain matters (Table 1: B cell). Delibera-

\footnotetext{
${ }^{3}$ According to Barry (1996), the "normative character of sustainability as a public principle or social goal makes it conducive to democratic as opposed to non-democratic forms of will formation" (116).
}

tion, as the only participatory mechanism that can promote the change of governmental policies through the free and unconstrained exchange of ideas amongst public and private actors, can not logically be applied to this broad audience (Table 1: C cell). Stakeholders are offered a varied number of participatory techniques because this is the correct and only way to carry out DS but also, more instrumentally, because these groups can contribute to improving the policy by means of their expertise and resources. Further, stakeholders' participation is likely to reduce the number of veto players in the implementation phase and is bound to decrease boycott strategies. Yet, most participatory mechanisms for this narrow audience have revolved around information and consultation mechanisms (Table 1: D and E cells), whereas truly deliberative techniques have rarely been put into practice (Table 1: F cell) ${ }^{4}$. The third and final question about the "results" of participation refers to the following: "while effects from a failure to consult can be relatively easily documented [in terms of] policy deadlock, and implementation difficulties... the decisional consequences of particular participatory processes are more difficult to assess, because partnership and civil participation do not always lead to anticipated outcomes" (Meadowcroft 2004).

Table 1. The "who" and the "how" of participation

\begin{tabular}{lll}
\hline $\begin{array}{c}\text { Type of demos: } \\
\text { Type of participation: }\end{array}$ & Public & Stakeholders \\
\hline Information & $\begin{array}{l}\text { A)Yes, public } \\
\text { education }\end{array}$ & D) Yes, information exchange \\
B) Yes, participa- & E) Yes, social learning \\
tonsultation & $\begin{array}{ll}\text { C) No, unfeasible } \\
\text { Deliberation }\end{array}$ & $\begin{array}{l}\text { F) Yes, improved and consen- } \\
\text { sual decision-making and } \\
\text { cooperative implementation }\end{array}$ \\
\hline
\end{tabular}

Source: adapted from Aguilar (2004)

Diffusion and Lesson-Drawing in WFM

Alongside stakeholders' participation, and following another important element associated with governance, forest policy has also been subject to horizontal mechanisms based upon learning, imitation or lesson-drawing. These mechanisms operate through diffusion processes which generally adopt the shape of networks ${ }^{5}$. Cross-national diffusion constitutes, together with multilateral negotiation (or harmonization) and unilateral imposition, "a third and distinct mode of global governance". Whereas harmonization refers to the "conscious modification of internal policies by governments committed to multilateral standards that they have had a hand in drafting", and imposition happens when certain actors "use asymmetric power relations to dictate their policies to other states", diffusion operates differently. Diffusion is a "proc-

\footnotetext{
${ }^{4}$ Participation can become a "legitimating device", in the sense that governments pay lip-service to the principle in order to justify their flawed strategies and continue doing business as usual" (Aguilar, 2004, 143).

${ }^{5}$ This section draws primarily on Jörgens (2004).
} 
ess by which an innovation is communicated through certain channels over time", "it is a process of imitation or learning where information about innovative practices in one setting affects policy choices in another". Unlike harmonization and imposition, this is a decentralized and rather voluntary process that entails no formal obligation (246-53) (Table 2). Since the EU framework for forest management does not constitute a proper policy, forestry-related issues have been basically affected by diffusion and, to a lesser extent, by imposition.

Table 2. Different Modes of Global Governance

\begin{tabular}{|c|c|c|c|}
\hline & Harmonization & Imposition & Diffusion \\
\hline $\begin{array}{l}\text { Mode of } \\
\text { operation }\end{array}$ & $\begin{array}{l}\text { Multilateral } \\
\text { cooperation } \\
\text { and decision- } \\
\text { making }\end{array}$ & $\begin{array}{l}\text { Unilateral } \\
\text { conditionality } \\
\text { (political or } \\
\text { economic) }\end{array}$ & $\begin{array}{l}\text { Decentralized imitation, } \\
\text { persuasion/learning }\end{array}$ \\
\hline $\begin{array}{l}\text { Level of } \\
\text { obligation }\end{array}$ & $\begin{array}{l}\text { Medium to } \\
\text { high }\end{array}$ & High & Low \\
\hline $\begin{array}{l}\text { Principal } \\
\text { motivation of } \\
\text { national } \\
\text { policy-makers }\end{array}$ & $\begin{array}{l}\text { Address } \\
\text { transboundary } \\
\text { problems; } \\
\text { avoid trade } \\
\text { distortions }\end{array}$ & $\begin{array}{l}\text { Join existing } \\
\text { international } \\
\text { organizations } \\
\text { or treaties; } \\
\text { obtain financial } \\
\text { or technical aid }\end{array}$ & $\begin{array}{l}\text { Search for solution to } \\
\text { domestic problems; reduce } \\
\text { uncertainty; avoid negative } \\
\text { externalities of other state's } \\
\text { actions; gain internal and } \\
\text { external legitimacy }\end{array}$ \\
\hline $\begin{array}{l}\text { Principal } \\
\text { driving force }\end{array}$ & Interest & Power & Knowledge \\
\hline
\end{tabular}

Source: Jörgens (2004).

Thus, diffusion mechanisms are on the rise in forest policy. They generally start out as an exercise of persuasion, when some countries get convinced to follow certain forestry-related (or WFM) practices which, having been previously adopted by a small number of pioneering states, have provided effective solutions to specific problems. Later on, pressures for conformity, or the desire to avoid future economic or political disadvantages, can function as a powerful force to explain diffusion ${ }^{6}$. Diffusion is carried out through trans-national channels of communication that basically adopt the shape "of international or global issue networks where state and non-state actors meet on a regular basis to exchange information and to coordinate national policies and programmes" $(255)^{7}$. These networks have been identified in forest policy, more specifically in certain Southern European countries, as it will be later shown.

EU forestry-related issues have nonetheless been influenced by imposition as well. That is, all countries willing to join the European club are "forced" to fulfil certain prerequisites, the

\footnotetext{
${ }^{6}$ If the pioneering state (or group of states) succeeds in persuading the EU about the goodness of a particular policy, and the EU transforms this policy into law, then diffusion becomes harmonization. EU air pollution control policy, for instance, has been heavily influenced by pioneering legislation in Germany (Aguilar, 1997).

${ }^{7}$ These networks embrace trans-national advocacy networks and epistemic communities, intergovernmental networks of policymakers, experts and NGOs, and international organizations (255).
}

Springer acceptance of the acquis communautaire being a crucial one although generous deadlines and opt-outs have been permitted in some cases. This has been the case of countries that, after experiencing dual transitions to democracy and the market economy, have become EU members or are still looking forward to joining it: anticipating accession, these countries have adopted the $a c$ quis or adapted their legislation to European rules. In spite of the fact that forestry is not part of this acquis, all the programmes, decisions, and actions adopted by the EU in this field have been clearly subscribed to (as a sign of good political will) by newcomers. Subscribing to the EU forest framework may be simply a rhetorical exercise or may be taken seriously, above all if the reception of funds is made conditional on the application of certain measures. This possibility can be linked to our previous discussion about stakeholders' participation: in some cases, participation might only be successfully implemented if international financial contribution is made conditional on the application of a dialogue between authorities and target groups (economic conditionality); another mechanism whereby international recommendations might be subscribed to by those countries emanates from political processes leading to the accession to regional political regimes (political conditionality).

\section{Governance and Sustainable Development in EU Forest Policy}

Governance and SD have thus affected a broad array of public policies, forest policy not being an exception to the rule. In 2001, the European Council approved a SDS ("A Sustainable Europe for a better world: A European Strategy for SD") and, five years later, a (renewed) SDS for an Enlarged Europe came into place and incorporated a new governance structure. This approach has been universally accepted and consequently permeates policy proposals, white papers and documents of various sorts, and legislative outputs on different levels: international (United Nations, the European Council, the EU), national, regional and local.

Forest policy embraces a set of strategies, measures and actions (that might adopt or not the shape of legislative outputs ratified by national parliaments) directed at forestland planning and forest management (Glück and Voitleithner 2004). The degree of comprehensiveness (in terms of the number of aspects touched upon), precision (the definition of specific objectives and deadlines) and innovation (the adoption of novel approaches and procedures, this including the combination of different policy tools that do not strictly stick to command-and-control instruments) of these strategies differ amongst countries. In spite of this variety, that can be explained not only by different political willingness and administrative capacities, but also by the necessity to take into account different social, economic and environmental circumstances (in line with the tailored policies that SD promotes), some convergence can be detected. That is, over the last decades of the 20th century, forest policies have changed in line with international commitments which have been basically promoted by the UN. International regimes (such as the EU) and 
individual states participating in different UN-promoted fora (such as the 1992 Rio Summit ${ }^{8}$ ) have incorporated these commitments. As a consequence of the Rio Summit, for instance, the European Council approved a Resolution on a Forestry Strategy for the EU in 1998. Later on, the EU devised its Forest Action Plan (FAP) (2007-2011) ${ }^{9}$, as a framework and coordinating programme that stressed sustainable forestry management and the multifunctional role of forests. Emphasis was also placed upon the need for greater coherence, coordination, competitiveness (in line with the Lisbon strategy) and good governance in the field. Subscribing to the subsidiarity principle, the FAP is based on N/RFP which, in line with SD, allow for a broad range of contents.

The FAP embraces a number of key actions to be jointly undertaken by the Commission and the state members, as well as a number of complementary actions that fall under the responsibility of national governments. All actions are to be implemented by means of working programmes that detail specific activities under each key action, leading actors, timeframes or deadlines, working instruments or policy tools, outputs and results. Those actions can be summarized as: (1) increasing long-term competitiveness through the promotion of $\mathrm{R}+\mathrm{D}$, information exchange on the marketing of forestry goods and services other than timber, biomass use, the cooperation between forest owners ${ }^{10}$ as well as education and training; (2) improving the protection of the environment through the compliance with the Kyoto Protocol, the fulfilment of biodiversity objectives, and the creation of an information system (Forest Focus); (3) contributing to a better quality of life by exploring the multi-faceted potential of urban forests, strengthening the role of the Standing Forestry Committee (set up in 1989) that will focus on voluntary (or open) coordination of NFP; (4) reinforcing the role of the EU in the international arena.

In spite of this forest scheme, a common EU forest policy is not in place yet: responsibility for forest planning and WFM is in the hands of member states which, more or less freely (through tailored national and regional programmes), adjust to the guidelines established by the EU. That is, unlike many other policies (such as environmental protection), EU forest-related goals do not enjoy a compulsory character and can not be therefore enforced by EU institutions ${ }^{11}$ : only trade-connected issues fall

\footnotetext{
${ }^{8}$ The Rio Summit produced the Forest Principles as well as Agenda 21, whose 11th chapter deals with deforestation issues.

${ }^{9}$ As a previous step, Europe officially endorsed the UN's Forest Principles in 1990, following the Ministerial Conferences on the Protection of the Forests of Europe, which have embraced a set of resolutions aiming to promote sustainable forest management. These resolutions are also implemented through NFP.

${ }^{10}$ The Advisory Group on Forestry and Cork is devoted to promoting cooperation with stakeholders.

${ }^{11}$ There is, however, EU legislation and also support measures in a number of policies that impinge upon forest management. Forestryrelated EU actions can be explained by the existence of overlapping and inter-sectoral issues in policies related to internal market, trade and competition, CAP and rural development, environment, enlargement, $\mathrm{R}+\mathrm{D}$, research, energy and the like. In line with the increasing use of cross-sectoral approaches, disaggregation of the boundaries between
}

under the exclusive remit of the EU (a hybrid organization that combines intergovernmental and supranational features although it functions as a single entity when it comes to signing international agreements in this field). From and institutional point of view, there is no single Directorate General (DG) with forest responsibilities in the $\mathrm{EU}$, and the policies that impinge upon forestry (such as agricultural, environmental, energy, regional... policy) are distributed amongst different DGs, making coordination in this sector a challenging task.

Even though international commitments are not compulsory, forest policies are being rapidly updated to keep up pace with recent changes in the international scenario, as acknowledged by the UN itself. In line with this process, references to participatory and holistic approaches, sustainable management, certification schemes and economic viability, amongst others, are found in forest documents everywhere. Intense internationalization of this policy has then created some convergence, as exemplified by the adoption by countless countries of N/RFP whose content is permeated by SD and governance principles. Yet some relevant differences, or sui generis elements, in N/RPF still exist and they have to do with: (1) those Central and Eastern European countries that, after experiencing dual transitions to democracy and the capitalist economy, have undertaken restitution mechanisms to devolve forest property to their initial owners ${ }^{12}$; (2) the varying mix of public/private forest land; this ranges from countries where land is mostly in public hands (such as Greece) to those where forestry assets are mainly private (as the Slovenian case shows, with $3 / 4$ of the land belonging to private owners); (3) the different economies of scale associated with varying degrees of fragmentation of the forest land: the higher the number of smallsized properties in private hands, the more difficult it is to undertake efficient management mechanisms (Slovenia is again an example of fragmented private ownership which does not facilitate forest economic viability, expertise in forestry management or the creation of powerful associations in the sector); (4) the unequal distribution of institutional capacities, existing expertise and availability of funds, plus the heterogeneous landscape regarding the existence of (or absence thereof) well-entrenched participatory processes.

Governance and WFM in the EU

One of the common goals in European, but especially in Southern European, N/RFP is the protection of forests from fires and

traditionally-conceived sectoral policies and recognition of growing overlapping responsibility, the current World Bank forest strategy review has shown that intervention in sectors other than forestry has affected forests more importantly than forest policy itself.

${ }^{12}$ Alongside restitution mechanisms, some sort of suspicion related to the role of state in forestry-related issues can be perceived in former "Communist" countries. The case of the Czech Republic is clear in this respect when it declares the need to limit state interference to the minimum. Restitution plus state's reluctance to intervene has produced a private forest landscape. 
other hazards ${ }^{13}$. This element has not been sufficiently considered by most non-Mediterranean N/RPF, its changing importance being associated with the frequency and severity of the seasonal occurrence of wildfires (Montiel et al, 2008). Although increasing attention to wildfires can be detected in a larger number of countries over time, this is a subfield where only little convergence has occurred. Alongside changing climatic conditions, that might have brought about a growth of fires in previously lowrisk areas, some diffusion of best practices through different networks can account nonetheless for the emerging salience of this issue.

A growing number of forest plans tend to include preventive and suppressive actions to mitigate wildfire hazard. Some recent trends in wildfire policy are directed towards taking long-term preventive actions; that is, the traditional approach based on ad hoc reaction and quick suppression measures in the face of catastrophic situations is being gradually replaced by proactive mitigation before the emergency arises (FAO, 1999; Montiel and San Miguel, 2009). A further step involves Integrated Fire Management (IFM), a concept that includes social, economical, cultural and ecological evaluations with the objective of minimizing the damage (and maximizing the benefits) of fire. IFM combines prevention and suppression strategies that integrate regulation of traditional burning and the use of technical fires (Rego et al., 2010). Alongside the objective of wildland defence against fires, specific legislation and policy instruments to protect human lives and goods have been adopted in European countries, at the national and regional level, in the context of civil protection policies. Thus, other policies need to be taken into consideration when analysing relevant measures that influence wildfire hazard and fire patterns: spatial planning, rural development and agricultural policies, energy and environmental protection are amongst these examples (Galiana et al 2011).

Stakeholders' participation and learning through diffusion mechanisms are badly needed in WFM: first, because local communities and private forest owners can be most easily mobilized in case of fire and are also supposed to exhibit intense preferences concerning fire regulation in their vicinities14; and, secondly, because these groups need either to learn ex novo or to recall how to use the fire to mitigate wildfire. Effectiveness of intervention on structural causes affecting wildland fires also

\footnotetext{
${ }^{13}$ Wildfires are one of the main risks affecting European forests, particularly in the Mediterranean countries. Even though the forestry surface has increased almost $7 \%$ over the past 15 years -and continues to do so although at a slower pace (FAO, 2005a), the forest sector is facing emerging challenges which are related to the management and conservation of resources (UNECE-FAO, 2005). Demographic and socioeconomic changes, certain forest actions connected with new plantations, and a number of policy measures outside the forest sector itself (i.e. environmental and nature protection policies) have increased the flammability of the ecosystems and the risk of large wildfires.

${ }^{14}$ The idea of different degrees of intensity in a given system of preferences, that comes from the choice theory, is useful here: it describes how, despite the fact that good preservation of a public good (the forest) might be in everyone's interests, the immediate winners or losers from a change (to the worse) in its preservation (the "neighbours" of the forest) will logically show more intense preferences than the general public on the whole.
}

depends to a large extent on the adaptation to the spatial and socioeconomic characteristics of the place considered. Three different types of fire scenarios, which demand different governance mechanisms, can be identified (Montiel and Herrero, 2010): Scenario 1: Disadvantaged rural areas, characterized by serious rural depopulation and an uncontrolled expansion of nonproductive forests; Scenario 2: Dynamic rural areas, characterized by a consolidated socioeconomic context and productive forests; Scenario 3: Suburban rural areas and wildland-urban interfaces, which are highly vulnerable to fire because of extensive urban developments.

Existing stakeholders in each scenario have to be identified as well as their abilities to participate in wildfire integrated management schemes. Only then will it be possible to outline influencing factors in each fire scenario and also to suggest efficient governance mechanisms adapted to local opportunities and limitations (Table 3).

Fire as a friendly tool: bringing old practices back

Since ancient times, fire has been an important cultural element used for multiple purposes: agriculture, grazing, forestry, hunting, industry (Ribet, 2008). The FAO itself has acknowledged the fact that fire has been an ever-present factor in the European landscape, being widely applied to agricultural and forest practices, both in the past and presently (FAO, 2006). Outside Europe, "indigenous Australians adapted their lifestyles and land management practices to fire regimes over thousands of years" for instance (Hughes and Mercer, 2009, 124).

Many high-value landscapes in Europe have been created, maintained and/or shaped by human burning (Pyne 1997; Goldammer 1998, 2000). For instance, fire in Spain (both in the Atlantic-Cantabric-Plateau and in the Mediterranean region) has been the most extended tool for stubble burning and grazing improvement in mountain areas (Vega and Vélez, 2000); in France, particularly in the Pyrenees, the relationship between human intervention and the environment has been expressed through the use of fire for millennia (Métailié, 2006; Lambert, 2008): pastoral fires in rangelands (écobuages) constituted an irreplaceable tool to "clean up" abandoned agricultural lands invaded by wild vegetation and also to increase its productivity. In Greece, burning has been practiced by shepherds for a long time with range improvement purposes (Papanastasis 1977) (see Fig. 1).

In spite of being a well-entrenched practice, wildfire policies adopted by most European countries have been based on total fire exclusion over the last century. Lack of understanding about traditional fire practices by certain forest services can explain this approach (Ribet 2008; Lambert 2008). Some countries have classified these practices (mostly pastoral fires) as dangerous activities and have, therefore, imposed a total ban upon them; some others have chosen, however, to regulate them through permits. Quite recently, some criticism has been levied against, first, lack of recognition of the role of fire in the maintenance of ecosystems and, secondly, deficient understanding about the socio-economic and cultural conditions under which many fires 
have occurred. As Hughes and Mercer (2009) point out: "contemporary society must ...learn to embrace fire as a natural phenomenon and accept that nothing can be done to completely eliminate it, while at the same time recognising that much can be achieved to mitigate some of fire's most destructive impacts"
(124). In line with this view, fire is being gradually reintroduced in a number of countries (some Mediterranean areas pioneering this approach) as a mechanism to reduce hazardous fuels and other types of forest-related risks (Hesseln 2006).

Table 3. Governance mechanisms in different fire scenarios

\begin{tabular}{|c|c|c|c|}
\hline Scenarios & Stakeholders & Opportunities/limitations & Government mechanisms \\
\hline $\begin{array}{l}\text { 1. Disadvantaged rural } \\
\text { areas }\end{array}$ & $\begin{array}{l}\text { Local communities, forest } \\
\text { owners, managers, politicians, } \\
\text { fire-fighters }\end{array}$ & $\begin{array}{l}\text { Forests are not economically considered } \\
\text { No reason for social mobilization against fires } \\
\text { Lack of forestry management and disinterest } \\
\text { about forest protection }\end{array}$ & $\begin{array}{l}\text { Subsidies for preventive silviculture } \\
\text { Actions for forest "extension" } \\
\text { Job creation through wildfire management tasks } \\
\text { Control of traditional fire burns through regulation and } \\
\text { follow-up }\end{array}$ \\
\hline 2. Dynamic rural areas & $\begin{array}{l}\text { Rural population, forest own- } \\
\text { ers, forest users, sector-related } \\
\text { entrepreneurs, managers, } \\
\text { politicians, fire-fighters. }\end{array}$ & $\begin{array}{l}\text { Forests have an economic value and need to be } \\
\text { protected. } \\
\text { Stakeholders wish to play an active role in } \\
\text { forest protection. } \\
\text { Conflicts between different interests }\end{array}$ & $\begin{array}{l}\text { Active participation of forest professionals in preven- } \\
\text { tion and extinction tasks is organized Inter-sectoral } \\
\text { coordinationFire use expertise Efficient fire defence } \\
\text { mechanisms }\end{array}$ \\
\hline $\begin{array}{l}\text { 3. Suburban rural areas } \\
\text { and wildland urban } \\
\text { interfaces }\end{array}$ & $\begin{array}{l}\text { Inhabitants (locals and immi- } \\
\text { grants), forest urban users, } \\
\text { urban associations, } \\
\text { fire-fighters, owners, managers, } \\
\text { politicians. }\end{array}$ & $\begin{array}{l}\text { Non-existent risk culture and risk awareness } \\
\text { Availability of powerful and efficient fire } \\
\text { extinction services } \\
\text { High degree of vulnerability of forests and } \\
\text { communities in the face of fires }\end{array}$ & $\begin{array}{l}\text { Active prevention through spatial planning instruments } \\
\text { Conciliation and compensation mechanisms as a result } \\
\text { of limitations upon urban demands, through the coordi- } \\
\text { nation with different types of associations } \\
\text { Awareness-raising, education and information about } \\
\text { forest risks } \\
\text { Wildland-urban interfaces inhabitants' involvement in } \\
\text { self-protection measures }\end{array}$ \\
\hline
\end{tabular}

Source: Own elaboration

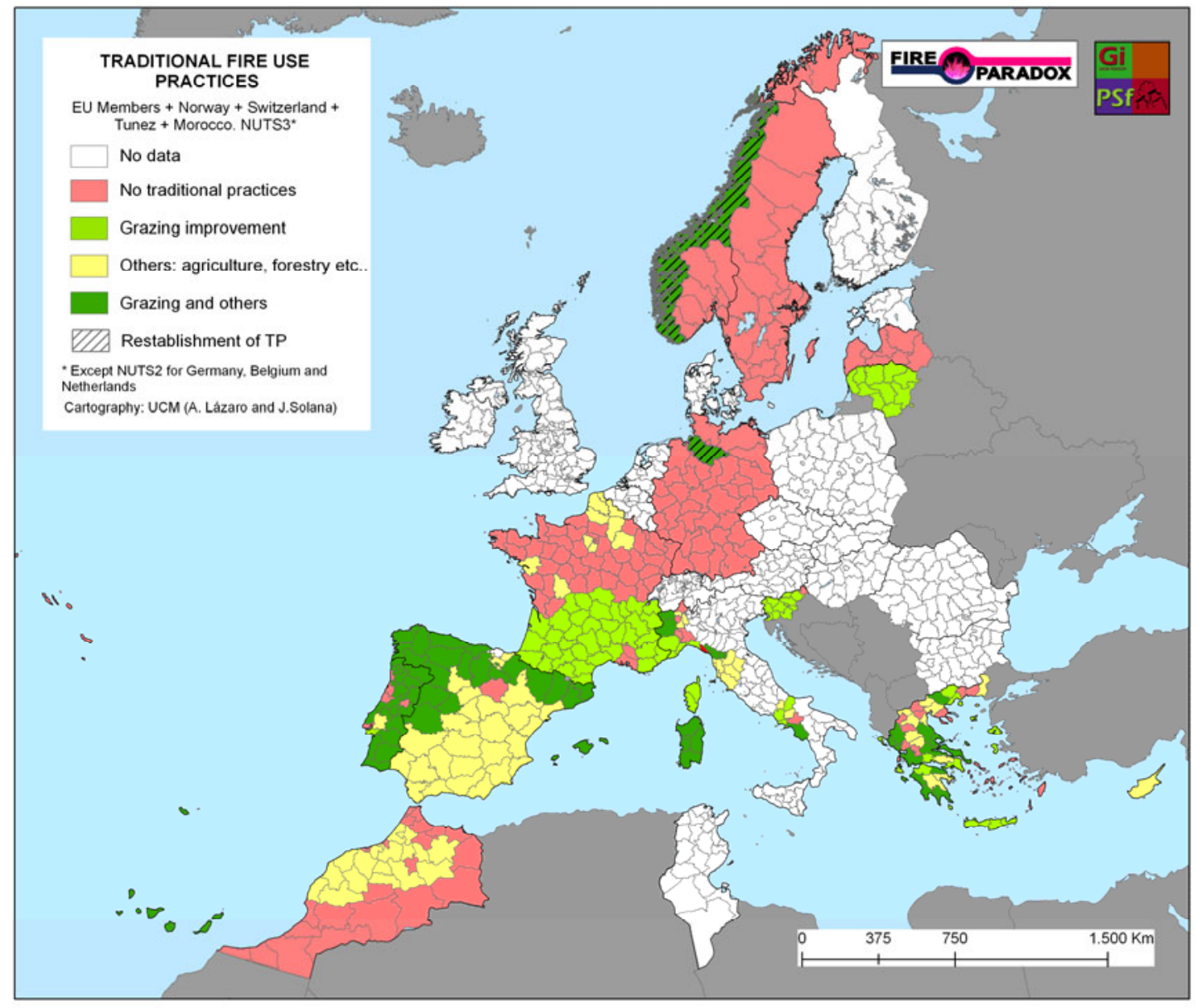

Fig. 1 Traditional burning practices in Europe and North African countries

Source: Lázaro and Montiel (2010) 
Social and economic changes during the second half of the 20th century, in some cases adopting the shape of abandonment of primary sector activities and unsustainable planning, seem to go against the revival of these old practices. For instance, demographic and spatial changes in forest contexts (rural depopulation plus the concentration of population in peri-urban areas, amongst others) have contributed to the increasing flammability of ecosystems while traditional fire practices have become risk activities at the same time. Further, these changes have also paved the way to modifying the traditional use of fire: from a cultural practice undertaken by rural societies, it has frequently become clandestine and uncontrolled burning usually performed by individuals (Métailié 2006). This modification has originated a conflict of interests between locals, who want to use fire in order to control the outgrowth of vegetation (sometimes even without a permit), and forest services, trying to set limits upon these practices in order to prevent uncontrolled fires (Vélez 2005). Despite rural depopulation, forest fire databases show that most wild fires in the Mediterranean region are caused by the misuse of fire in rural activities (FAO 2006). This is the case of Spain, for instance, where around $60 \%$ of the total number of fires is directly related to this type of activity (Vélez 2005). In Italy, 17\% of the forest fires have their origin in agricultural fields, shrubs and pastures (DG JRC-IES 2005) ${ }^{15}$. The magnitude of this problem makes the application of educational prevention programs in rural societies a real priority ${ }^{16}$. It is also crucial to develop a policy of interest accommodation amongst the wide array of actors involved in different fire practices so that a consensus about fire use, which goes beyond the sheer prohibition of burning, is reached. In short, a thorough regulation of fire use practices in order to reduce wildfire hazard is badly needed in Southern Europe and other regions (Fig. 2).

In spite of the problematic situation related to the misuse of fire, new opportunities are opening up for fire use techniques, such as prescribed burning (PB) and suppression fire (SF), in forest and fire management and also in conservation policies. PB is the deliberate and accurate application of fire to forest fuels under specified conditions so that concrete and well-defined management goals are attained (Wade and Lunsford, 1989). The main difference between PB and the traditional use of fire is the existence, in the first case, of adequate evaluation techniques which help determine whether certain objectives have been fulfilled or not (Pyne et al. 1996; Fernandes 2002). These techniques were introduced in Southern European countries (Portugal, Spain and France) in the early eighties (Botelho and Fernandes, 1998), their application depending on the degree of public awareness and the type of knowledge about fire ecology and fire management (FAO, 2006). On the other hand, SF is one of the

\footnotetext{
${ }^{15}$ In Greece, fires set by shepherds in overgrazed shrub-lands are a significant problem since they amount to more than $10 \%$ of all wildfires in the country (Xanthoupoulos et al, 2007).

${ }^{16}$ Programmes that aim to sensitizing rural populations about the risk of uncontrolled burning have been carried out in some cases - for instance, in Spain- but their degree of success has not been evaluated yet.
}

most ancient fire techniques and a well known practice in Europe to fight wildfire, although only two countries (Portugal and Spain) have legal definitions about it. Fire has been used as a wildfire fighting tool by locals before the fire-fighter services were created in Europe. At present, fire-fighters are also starting to consider the possibility of using fire as a complementary tool. This technique entails a social, political and technical challenge: social acceptance and adequate regulation, as well as cooperation between different stakeholders, have to be attained if SF is to be effectively applied.

\section{Introducing Southern Europe: Is there a Mediter- ranean Syndrome?}

Application of (or absence thereof) real participatory mechanisms in public policies have to do, amongst other things, with well-entrenched political habits and institutional traditions: in some countries long-established consensual politics can be identified whereas, in others, governments are more prone to impose -without previous negotiation- their objectives. The institutional framework (federal and highly decentralized countries contain regional actors that have a say in certain policies) and the type of public/private arrangements in specific areas (some policies might contain old and powerful associations that, despite specific political habits in the country, have managed to establish themselves as inevitable co-agents in the decision-making process) are also important factors to be borne in mind. Generally speaking, broad and deeply rooted social participation in policymaking is less frequent in Mediterranean countries than in other EU member states. This situation can be basically explained by the existence of weak interest groups and by the strong "dirigiste" tradition of the state. Alongside the prevalence of top-down approaches, there are other factors that might also impair the application of governance mechanisms in Southern Europe: an important degree of institutional fragmentation and coordination difficulties are amongst these factors. All these problems seemed to be the reason for a comparatively worse compliance with EU environmental law (amongst others) in the region, a fact which has led in turn to the coinage of the term "Mediterranean Syndrome". However, the idea that Southern European countries could be grouped together under the same label has recently been dismissed: according to Börzel (2003), both "northern leaders" and "southern laggards" face compliance problems if a particular European policy is not compatible with their domestic regulatory structures. This would mean that the identification of a NorthSouth divide is therefore much more complex than it was previously (and hastily) thought.

Setting the context for WFM in Southern Europe: institutional frameworks and political outputs

As we have seen, political habits and institutional traditions influence the way in which forest policy (or, more specifically, WFM) is organized and carried out in different countries. Stick- 
ing to institutional frameworks alone, the Southern European scenario is most heterogeneous, ranging from centralized countries, somehow practising national (top-down) policies (e.g.,
Portugal and France), to decentralized countries, with many different regional (bottom-down) policies (e.g. Spain and Italy).

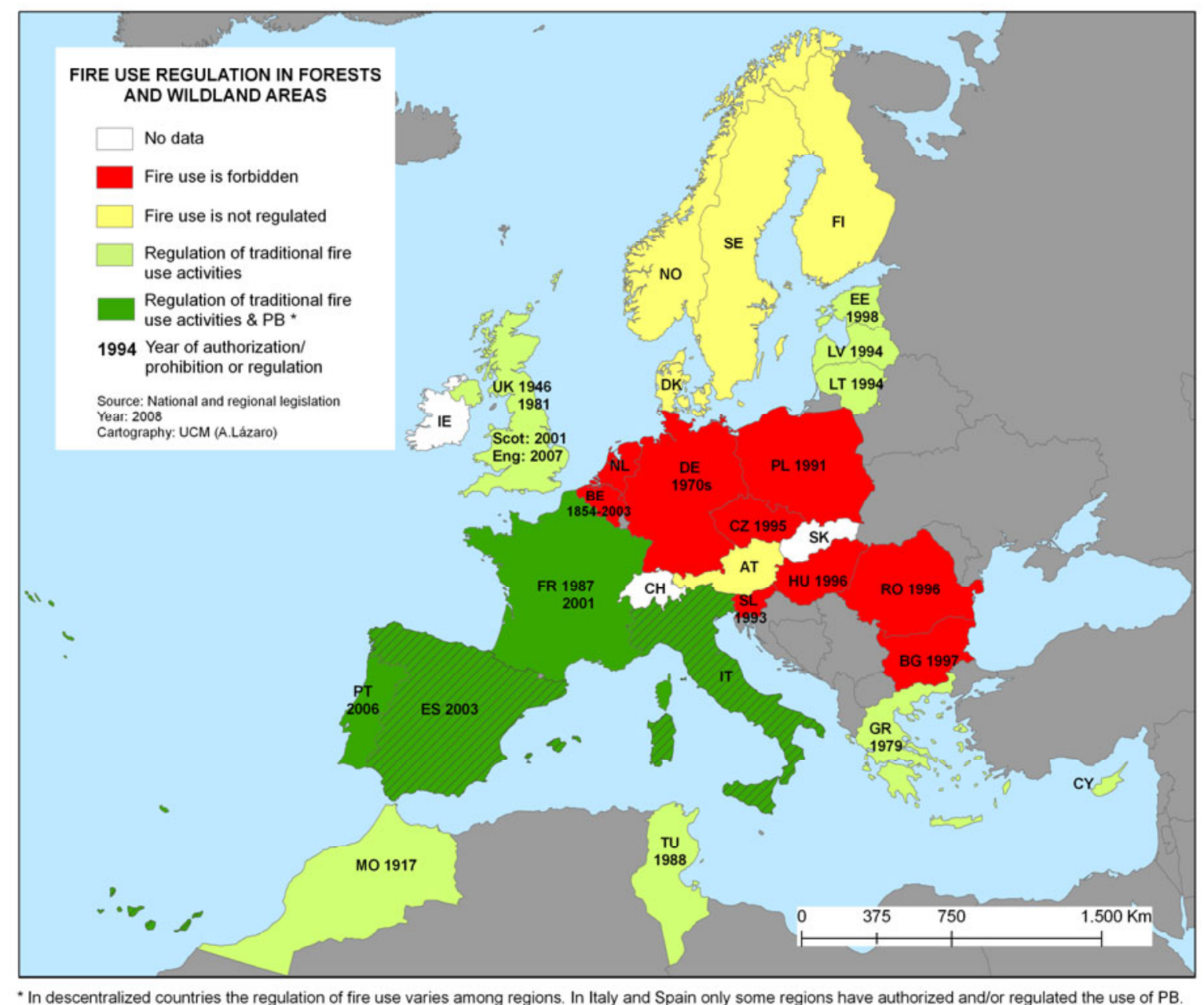

Fig. 2 Fire use regulation in forest and wildland areas in European and North African countries Source: Herrero et al. (2008)

In Portugal, Civil Protection (SNBPC) has the responsibility for fire suppression, while the Forest Service (the DirectorateGeneral, DG, for Forest Resources) coordinates prevention, and the National Guard (GNR) deals with fire detection, research and law enforcement. Wildfire policy is located in different ministries in France: the Ministry of Agriculture and Fishery (in coordination with the Ministry of Ecology and Sustainable Development) and the Ministry of Interior and Land Management deal with fire prevention while the latter coordinates suppression actions and aerial detection as well. Due to the existence of an asymmetrical model of quasi-federalism in Spain, actual responsibility for WFM is in the hands of 17 autonomous regions which have thus developed their own policy instruments and agencies. At the national level, the main unit dealing with fires is the Section of Defence against Wildfires (DG for Biodiversity, in the Ministry of Environment). In Italy, WFM is distributed between the Corpo Forestalle dello Stato (Ministry of Agriculture and Forest Policy), the National Civil Protection Department (Minis- try of Interior), the Corpo Nazionale dei Vigili del Fuoco, and the DG for Nature Conservation (Ministry of Environment). Uneven decentralization affecting the existing 20 Italian regions, five of which enjoy broader autonomy, paves the way, however, for a wide array of regional and local forest offices with different tasks, this being the reason why it is very difficult to obtain a clear picture of the Italian scenario.

When it comes to political outputs the situation is equally varied, even though some convergence, in terms of increasing acceptance of different fire techniques, can be detected in Portugal, France and Spain. The Portuguese Forest Policy Law (1996) contains the principles and goals of forest policy as well as the main policy tools to achieve these goals. However, it was not until 2003 that forest policy had its kick-off, the triggering factor for this "awakening" being the catastrophic summer in which 424000 hectares of forests and shrub-lands were burnt by large and uncontrolled fires in the same year. Increasing awareness among the population and decision makers about the importance 
of forests, whose value started to be perceived not only as economic but rather as environmental and social, can account for the "structural reform" which followed this disaster. The reform accelerated the elaboration of regional Forest Management Plans (PROF), which contained prevention, detection and fighting measures to tackle forest fires. Further, special legislative measures were taken to assure an integrated forest management approach. In 2006, a National Forest Strategy, which basically embraced a new forest institutional framework, was approved after active public consultation was undertaken. In the same year, the National Forest Fire Defence Plan was also passed and is now being implemented through regional plans. It is also important to mention that Portugal is one of the few EU countries that has criticised its own approach to forestry-related issues: this approach has been characterized as unduly interventionist, its legislative and planning impetus (with more than 68 pieces of legislation plus over 20 different planning instruments) leading to confusion and ignorance on the side of target groups. Since the exclusive emphasis on command-and-control tools has only decreased the credibility of the forest administration, a process of legislative streamlining has been recently undertaken. France started a process of intense forest policy reform in 1998 with the publication of the report, La forêt: Une chance pour la France (Bianco Report). Another relevant document was the Stratégie forestière, published one year later. The Forest Guidance Law, passed in June 2001, brought together all the proposals contained in the Bianco Report. These documents were essential for the presentation of a National Forest Programme (NFP), elaborated by the Ministry of Agriculture and Fishery for the 2006-2015 period and currently acknowledged as the main instrument to achieve the objectives of national forest policy. French forest policy can be considered a state policy, even though the regional level has been reinforced by means of the Orientations Regionales Forestieres (ORF), which are the equivalent to regional and/or sub-national forest programmes. In 1997, the Spanish DG for Conservation (within the Ministry for the Environment) decided to start out a two-stage reform process which paved the way for a new national forest policy. In the first stage, a consensus conducive to the drafting of a binding document called the Forest Strategy (FS) was reached. The FS presents the current state of forestry, the main problems in the sector and puts forward proposals to achieve sustainability in Spanish forests. Once published, the document led to the second stage of the reform, in which the 2003 National Forest Act (modified in 2006) and the 2002 Forest Plan, which gives shape to the political guidelines defined in the FS, were elaborated. The Spanish national forest policy can be characterized as rather complex because of the country's quasi-federal model, which contains 17 autonomous regions under the 1978 Constitution. Following the decentralization process which started out at the beginning of the $80 \mathrm{~s}$, responsibility for forest and fire management was transferred to the 17 regions. This situation has enabled policy reforms to be initiated at the regional level with the approval and implementation of regional Forest Plans, which have been subsequently incorporated into the National Forest Programme. Thus, the Spanish NFP does not only include the national government's FS and
Forest Plan but also the forestry-related documents approved and implemented at the regional level (Montiel et al 2006). As far as fire regulation is concerned, the National Forest Plan has designed a programme for wild-land protection against fires. Also at the national level, a Fire Defence Programme and a Civil Protection Plan for wildfire emergencies have been operating. Although the lion's share of the budget is assigned to suppression fire, preventive silviculture and social prevention are gaining importance in the Forest Plan. The first Italian National Forest Programme (NFP) was launched in 1985 and expired ten years later. Despite the absence of a new NFP, a general framework for agriculture and forestry issues was given by the Documento di Programmazione Agricola, Agroalimentare, Agroindustriale e Forestale (2001-3) after 1995. Since January 2000, the objectives contained in the NFP have been incorporated into the regional Rural Development Programmes, elaborated and implemented by 19 regions and two autonomous provinces ${ }^{17}$. These programmes, covering the 2000-6 period, function as a framework for all agriculture and forestry-related activities at the regional and local levels, and they also provide guidance and funds in order to implement national forest policy. At present, a new NFP, called Framework Programme for the Forest Sector, is being drafted by a committee headed by the Ministry of Agriculture and the Ministry of Environment. It is closely following the EU Forest Action Plan and the Ministerial Conference for the Protection of Forests (MCPF) principles. Unlike Portugal, Italy can be considered a laggard when it comes to fire regulation: there is no national fire plan, although the December $20^{\text {th }} 2001$ decree sets out some guidelines regarding WFM which will be have to be developed by the regional wildfire plans. At the regional level, responsibilities for WFM are distributed differently: some regions (such as Sardinia, Sicily, Friouli, Val d'Aosta) enjoy special autonomy, this allowing them to have a regional Corpo Forestalle. On the whole, Fire Brigades (Civil Protection) carry out prevention and suppression actions (a summary of forest and WFM policies is to be found in Table 4).

Fire networks in Southern Europe: think global, act local

Learning processes that help diffuse best fire practices in the Mediterranean countries are still in a rather embryonic state. As learning is increasingly subject to diffusion through networks, the following ones have been identified in the region: Red de Foco Controlado (RFC), in Portugal; Réseau de Brûlages Dirigés (BD), in France; and Equipos de Prevención Integral de Incendios Forestales (EPRIF), in Spain. Even though no Italian network is currently operating, the country is gradually incorporating some fire techniques in particular cases. Fire networks generally discuss and exchange ideas about experimental practices that have been developed by scientific institutions. A different thing is, however, to put these practices into work in situ. For

\footnotetext{
${ }^{17}$ There are 20 Italian regions but the powers of the region of Trentino Alto Adige/Südtirol are mostly exercised by its two autonomous provinces: Trento and Bolzano-Bozen.
} 
Table 4. Summary of Forest and Wildfire Policies in Southern Europe

\begin{tabular}{|c|c|}
\hline Country & Forest and Wildfire Policies \\
\hline France & $\begin{array}{l}\text { The main guidelines of the National Forest Programme are valorisation and increasing competitiveness of forest products under a sustainable de- } \\
\text { velopment scheme (and also the promotion of biomass as an energy source). Wildfire management is not included as a priority but it is a horizontal } \\
\text { objective which is part of broader operational programmes. } \\
\text { No National Plan on Wildfires exists; fire policy is nevertheless developed through Fire Protection Plans at the sub-national level. There are forest } \\
\text { protection plans against fires at the région or département; and risk prevention plans at the scale of commune. } \\
\text { The main topics developed by fire prevention policy are: risk forecast; surveillance and rapid fire detection; preventive sylviculture and defensive } \\
\text { infrastructures; public awareness and professional training. }\end{array}$ \\
\hline Italy & $\begin{array}{l}\text { Wildfire management is mainly found within specific planning instruments better rather than within forest plans. } \\
\text { The institutional framework locates planning responsibilities for fire prevention and defence in the regions. Wildfire management is developed } \\
\text { through regional plans whose contents are adapted to specific local contexts - even though a common structure is established at the national level. } \\
\text { Wildland fire management contains four main axis: prevision, prevention, suppression and cause investigation. }\end{array}$ \\
\hline Portugal & $\begin{array}{l}\text { The National Forest Strategy (NFS) and the National Fire Defence Plan (NFDP) are recent documents. The NFS states that proper forest fire man- } \\
\text { agement is linked to the sustainable development of forests. Regarding fires, a reduction of the burnt area is the main objective. The NFDP integrates } \\
\text { a thorough set of actions for wildfire management: prevention, pre-suppression, extinction and restoration. Transversally, professional training, } \\
\text { public information, legislation and safety of fire teams are included. } \\
\text { At the regional level, Forest Plans (PORF) include the wildfire topic. }\end{array}$ \\
\hline Spain & $\begin{array}{l}\text { The National Forest Plan contains a programme for wildland protection against fires. Besides, a specific Fire Defence Programme and a Civil Pro- } \\
\text { tection Plan for wildfires emergencies are to be found at the national level. } \\
\text { Most efforts and budgets are assigned to suppression. However, preventive silviculture and preventive social measures are becoming more impor- } \\
\text { tant. }\end{array}$ \\
\hline
\end{tabular}

Source: Own Elaboration

Experimental experiences: Notwithstanding "legislative overburden" and a belated awakening to forestry-related problems, Portugal has pioneered some fire practices in the EU: for instance, it has been the first country to use PB for fire hazard reduction. From the very beginning, the main objective of this decision was to test the adequacy of this technique in the Portuguese context, being then applied to different ecosystems at a later stage (basically, shrub-lands and maritime pines) (Botelho and Fernandes, 1998). PB is now a consolidated practice in public-owned forests located in Northern and Central regions (Salguiero, 2006) ${ }^{18}$. The most relevant scientific research centre in PB experimental studies is the University of Tras-Os Montes e Alto Douro. Following the Portuguese experience, France introduced PB in the 1980s, the Forest Fire Prevention Unit (within the Institut Nationale de la Recherche Agronomique, INRA, Avignon), which belongs to the "fuelbreak working group" (Réseau Coupures de Combustible), testing its feasibility in the Mediterranean region (Rigolot, 1995). The combination of PB techniques with other fuel management options is an important element of the research project developed by the INRA. In Spain, the Centro de Investigaciones Forestales y Ambientales in Lourizán is actively involved in PB experimental studies. Some experimental burning with interesting results has been carried out in the North-western region of Galicia. Although PB is not a common practice yet and has only been used locally and rather

\footnotetext{
${ }^{18} \mathrm{~A}$ list of the most important forestry and fire-related official texts in Southern Europe is to be found in the annex.
}

sporadically, other regions such as Asturias, Castilla and León, and Catalonia have been pioneers in its gradual application. In most Italian regions, PB is neither used nor even legally permitted; only a few regions (such as Basilicata, Piemonte and Liguria) have included this technique in their legislation but have not yet put it into practice. Yet, new experiments are being recently conducted by the Agroselviter Department of the University of Torino: the use of PB for the management of particular biotopes and for the reduction of fuel loads are the main aims of these experiments (Ascoli et al, 2009).

Operational experiences: Portugal has set up a number of specialized groups in wildland fire prevention (sapadores florestais) which, together with PB technicians, carry out prescribed and controlled rural burnings. Further, the sapadores have responsibility for public awareness campaigns, as well as detection and suppression duties. Since 2003, PB training programmes have been developed in order to certify technicians and train the sapadores (Salgueiro, 2006). The Grupo de Análise e Uso de Fogo (GAUF), a specialized team in wildfire assessment and fire use, has been recently created in order to ease the operational implementation of fire use techniques in fire management. French Mediterranean departments have established an active PB network which has carried out a total of 28 prescribed burning since 1990. These departments contain 25 specialized teams with different professional profiles. In between 4000 and 5000 has are subject to PB every year (Lambert, 2008), the main aim of this technique being the prevention of wildfires and, gradually, the solution of environmental problems (Rigolot, 2005). Mediter- 
ranean departments are part of the National Network for Prescribed Burning Teams, which is currently coordinated by the SUAMME (Service d'Utilité Agricole Interchambres Montagne Mediterranéenne Élevage). The main objectives of this network are knowledge-transfer, experience exchange, training and dialogue stimulation between different stakeholders (Rigolot 2000). Over the last years, Spain has developed a similar figure to that of the Portuguese sapadores, but with an important focus on wildland fire prevention: the Equipos de Prevención Integral de Incendios Forestales (EPRIF). They were created by the state government to cooperate with those autonomous regions that were located in high risk areas. These teams are composed by four technicians specialized in wildfires as well as in PB (Brigadas de Refuerzo de Incendios Forestales, BRIF) (Vélez, 1998). Their duties basically embrace wildland fires investigation, rural awareness campaigns, and the promotion of PB to eliminate clandestine burnings. Some regions have also created their own specialized teams: for instance, Castilla and León has developed a broad social prevention programme regarding wildfires, called Plan 42, whose philosophy is the same one as that of EPRIF and which includes $\mathrm{PB}$ as one of its main pillars. A different approach has been adopted by the Catalonian Fire Service, a specialized team set up in 1999 to support wildfire suppression operations through the incorporation of SF into conventional fighting strategies. As mentioned before, only a few Italian regions have included PB in their legislation but, except for Sardinia where this technique is used for fuel break maintenance (Leone, 1999), have not put it into practice. However, and following the request of a private land owner, the Pianacci Prescribed Burning Project for fire risk reduction and fuel load management has just been initiated in Florence (Tuscany Region) ${ }^{19}$.

\section{Conclusions}

The EU agenda in forest policy (more precisely in WFM) is clearly linked to SD and to the putting into practice of governance mechanisms. One of the most important of these mechanisms is broad social participation, which has to permeate all the different stages of the policy process (agenda-setting, the elaboration, formulation, implementation and enforcement of the policy, and the evaluation and proposal of policy changes). Stakeholders' participation is in line with the democratic man-

\footnotetext{
${ }^{19}$ Should we briefly consider other non EU-countries where fire is a most pressing problem, the approach to WFM would be different: in Australia, for instance, local government planning schemes are emphasized. More specifically, the Victoria Wild Fire Management Overlay innovatory approach, which has been subsequently followed by other states such as New South Wales and South Australia, has identified bushfire-prone areas, bushfire protection areas and entails the elaboration of bush fire risk management plans at the local level (Hughes and Mercer, 2009). Another example might be the California Fire Plan, which attempts both, to protect assets at risk through focused prefire management and to increase initial attack success
} (www.co.marin.ca.us/depts/FR/main/.../fireplan.cfm). date that underlies both sustainable and governance forestry. Further, given the complexities and uncertainties surrounding WFM, as well as the limited experience about the gradual reintroduction of PB and SF in Southern Europe, the incorporation of interested parties in the process is entirely unavoidable. Learning processes on different territorial levels (under existing multilevel polities), which are taking place through different mechanisms (networks, that diffuse best practices once experimental and operational actions have proven beneficial, are crucial ones), have to be exploited to the full in order to overcome wellentrenched animosities and prejudices affecting the different actors in WFM. New expertise and educational campaigns are obviously important resources, but so is the revival of old and wise, yet abandoned, fire practices that have traditionally been in the hands of rural communities. Although some progress in the use of fire can be detected in certain countries that have been seriously affected by wild fires, such as Portugal, the room for experimentation, diffusion and learning is still immense. In this respect, the EU should act as a gathering platform where best practices and initiatives could be discussed and exchanged amongst its member states, the role of Southern Europe in explaining the so-called fire paradox being most relevant in this scenario. As the environmental pioneer that has proved to be, the EU should also seize its leverage power to help transmit and disseminate these practices on the international level.

\section{References}

Aguilar Fernández SA. 1997. El reto del medio ambiente, Madrid, Alianza Universidad.

Aguilar Fernández SA. 2004. Sustainability is cool: rhetorical participatory discourse in the Spanish strategy for sustainable development. In: William M. Lafferty (ed), Governance for Sustainable Development: The Challenge of Adapting Form to Function. Cheltenham, UK: Edward Elgar Publishing Limited, pp.128-161.

Ascoli D, Beghin R, Ceccato R, Gorlier A, Lombardi G, Lonati M, Marzano R, Bovio G, Cavallero A. 2009. Developing an adaptive management approach to prescribed burning: a long-term heathland conservation experiment in north-west Italy. International Journal of Wildland Fire, 18(6): $727-735$.

Barry J. 1996. Sustainability, Political Judgement and Citizenship: Connecting Green Politics and Democracy. In: Brian Doherty and Marius de Geus (eds), Democracy \& Green Political Thought. London: Routledge.

Börzel T. 2003. Environmental leaders and laggards in Europe. Aldershot, Burlington, Singapore, Sydney: Ashgate.

Botelho H, Fernandes PM. 1997. Controlled burning in the Mediterranean countries of Europe. European Commission; Environment \& Climate Programme; Advanced Study Courses; Marathon; 6-14 October 1997. pp. $163-170$

DG JRC-IES. 2005. Forest Fires in Europe. Report $n^{\circ}$ 6/2005. JRC Scientific and Technical Reports, p.54.

FAO. 1999. Report of meeting on public policies affecting forest fires, 14th session, Rome, Italy, 28-30 October 1998, I. Part 1.

FAO. 2006. Fire management: Voluntary guidelines-Principles \& strategic actions. Fire management Working Paper FM17E. Rome. p.71. Available 
on www.fao.org/forestry/site/35853/en

Fernandes P. 2002. Prescribed fire: strategies and management. In: Pardini, G. and Pintó, J. (eds.), Fire, Landscape and Biodiversity: an appraisal of the effects and effectiveness. Diversitas 29. Universitat de Girona, Institut de Medi Ambient, Girona: pp.187-200.

Galiana L, Aguilar S, Herrero G. 2011. An assessment of the effects of forestrelated policies upon wildland fires in the European Union: Applying the Subsidiarity Principle. Forest Ecology and Planning (forthcoming).

Glück P and Voitleithner J (eds.). 2004. NFP Research: Its Retrospect and Outlook. Proceedings of the Seminar of COST Action E19 "National Forest Programmes in a European Context", September 2003, Vienna. Publication Series of the Institute of Forest Sector Policy and Economics - Vol.52, Vienna.

Goldammer JG. 1998. History of fire in land-use systems of the Baltic Region: Implications on the use of prescribed fire in forestry, nature conservation and landscape management. Paper presented in First Baltic Conference on Forest Fires, Radom-Katowice, Poland, 5-9 May 1998.

Herrero G, Montiel C, Agudo J, Aguilar S. 2008. Assessment document on the main strengths and weaknesses of the legislation and policy instruments concerning integrated wildland fire management in the EU, in European Member States and in North African countries. Deliverable D.7.1-1-2 of the Integrated project "Fire Paradox", Project no. FP6-018505, European Commission (available on http:// www.fireparadox.org).

Hesseln H. 2006. An assessment of domestic and foreign wildfire policy (unpublished).

Hughes R, Mercer D. 2009, Planning to reduce risk: the wildfire management overlay in Victoria, Australia. Geographical Research, 47(2): 124-141.

Jordan G. 1993. The new right and public policy: a preliminary overview. In: Grant Jordan and Nigel Ashford (eds.), Public Policy and the Impact of the New Right. London and New York: Pinter Publisher, pp.46-58.

Jörgens H. 2004. Governance by diffusion: implementing global norms through cross-national imitation and learning, In: William M. Lafferty (ed), Governance for Sustainable Developmen: The Challenge of Adapting Form to Function. Cheltenham, UK: Edward Elgar Publishing Limited, pp. 246-283.

Lafferty W. 2004. "Preface". In: William M. Lafferty (ed), Governance for Sustainable Development: The Challenge of Adapting Form to Function. Cheltenham, UK: Edward Elgar Publishing Limited.

Lambert B. 2008. Bilan et perspectives du réseau Brûlage Dirigé, 30p.

Lázaro A, Herrero G, Montiel C, Molina D. 2008, Organización de la defensa contra incendios forestales en el Estado de las Autonomías: el caso español., Revista Forestal Española, no. 40, pp. 13-20.

Lázaro A, Montiel C. 2010. Overview of prescribed burning policies and practices in Europe and other countries. In: Sande Silva, J., Fernandes \& Rigolot, E. (eds.), Towards Integrated Fire Management- Outcomes of the European Project Fire Paradox. European Forest Institute Research Report, 23, 137-150.

Leone V. 1999. Constraints and opportunities in prescribed burning development. Deliverable 1. FIRE TORCH project. Prescribed burning as a tool for the Mediterranean region: a management approach, p.43.

Meadowcroft J. 2004 Participation and sustainable development: modes of citizen, community and organisational involvement. In: William $\mathrm{M}$. Lafferty (ed), Governance for Sustainable Development: The Challenge of Adapting Form to Function. Cheltenham, UK: Edward Elgar Publishing Limited, pp.163-190.

Métailié JP. 2006. Mountain landscape, pastoral management and traditional practices in the Northern Pyrenées (France). In: Anoletti, M. (ed.), The conservation of Cultural Landscapes, CAB International, pp.108-124.

Mette Kjaer A. 2004. Governance. Cambridge: Polity Press.

Montiel C, and San-Miguel J. 2009. Policy analysis reveals the need for new approaches. In: Birot, Y. (ed.), Living with wildfires: what science can tell us. A contribution to the Science-Policy Dialogue, European Forest Institute, Discussion Paper 15, pp. 63-67.

Montiel C, Costa P, Galán M. 2010. Overview of suppression fire policies and practices in Europe. In: Sande Silva, J., Fernandes \& Rigolot, E. (ed.): Towards Integrated Fire Management- Outcomes of the European Project Fire Paradox. European Forest Institute Research Report, 23, pp. 177-187.

Montiel C, Herrero G, Lázaro A, Agudo J, Aguilar S. 2008. List and classification of the existing EU and national forest legislation and national policy instruments with reference to wildland, suppression and prescribed fires. Deliverable D.7.1-1-1 of the Integrated project "Fire Paradox", Project no. FP6-018505, European Comisión (available on http: www.fireparadox.org)

Montiel C, Herrero G. 2010. Overview of policies and practices related to fire ignitions. In: Sande Silva, J., Fernandes \& Rigolot, E. (eds.), Towards Integrated Fire Management- Outcomes of the European Project Fire Paradox. European Forest Institute Research Report, 23, 35-46.

Pyne SJ, Andrews PL, Laven RD. 1996. Introduction to Wildland Fire, 2nd edition. New York: John Wiley and Sons.

Pyne SJ. 1997. Vestal Fire. An environmental history told through fire, of Europe and Europe's encounter with the world. Washington: University of Washington Press.

Rego F, Rigolot E, Fernandes P, Montiel C, Sande Silva J. (eds.). 2010. Towards Integrated Fire Management, EFI (European Forest Institute) Policy Brief 4.

Ribet N. 2008. Le brûlage dirigé, une revolution plus politique que technique. INFO DFCI Bulletin su centre de documentation «Forêt Méditerranéenne et incendie », Juin 2008 No. $60: 1-4$

Rigolot E. 1995. Le brûlage dirigé en région méditerranéenne française. INFO DFCI Juin 1995 No.34, 1:3

Rigolot E. 2000. Le brûlage dirigé en France: outil de gestion et recherches asocies. In: Vega, J. A. \& Vélez, R (coord.), Actas de la Reunión sobre quemas prescritas, Cuadernos de la Sociedad Española de Ciencias Forestales, no. 9, pp.165-178.

Rigolot E. 2005. Brûlage dirigé: Quinze ans d'expérimentation. Espaces Naturales, no. 12, October 2005, 16-17

Salgueiro A. 2006. Le Portugal sans incendies, c'est un Portugal qui a intégre la gestion par le feu. In: Lambert \& Rigolot. XVII Rencontres des Équipes de Brûlage Dirigé. Rosans (Hautes-Alpes)- 7 au 9 Juin 2006. Edition La Cardère, $\mathrm{p} 44$.

Vega JA, Vélez R (coord.). 2000. Actas de la Reunión sobre quemas prescritas. Cuadernos de la Sociedad Española de Ciencias Forestales, no. 9, p.283.

Vélez R. 1988. El fuego prescrito en los planes de prevención de los incendios forestales. In: Proceeding of the International Workshop on Prescribed Burning, FAO March 14-18 1988, pp. 53-57

Vélez R. 2005. La población rural en la prevención de incendios forestales. Documento de Trabajo sobre Protección Forestal FFM/4/E, FAO, Rome

Wade D, Lunsford JD. 1989. A guide for prescribed fire in Southern forests. USDA For. Serv. Tech. Pub. R8-TP 11, Southern Region. Atlanta, Georgia. 